\title{
植物病害防除における薬剤耐性菌問題
}

\author{
黄 耿 堂 \\ 理化学研究所 \\ (昭和 53 年 6 月 5 日受理)
}

\section{Problems of Drug Resistance on Plant Disease Control}

\author{
Keido Ko \\ The Institute of Physical and Chemical Research, \\ Woko, Saitama 351, Japan
}

\section{植物病害防除における薬郕耐性菌問題}

数年前から起こった薬剤耐性菌問題は,急速に発展し， 植物病害防除上, 解決を急がなければならない重要な研 究課題となった. 18 世紀の初めから, 銅・水銀などの無 機化合物が種子消毒戍として, 使用されて以来, 農薬に おける長い歴史は, 硫黄郕・ボルドー液の時代を経て, 1930 年代の有機硫黄剤をはじめとする, 有機水銀㓮, 有 機ヒ素剂など，一連の金属を含む有機化合物の時代が続 いた．この時期の殺菌剤のほとんぞは，効果が高く，適 用範囲が広く, 選択性の少ないものが特徵的であり, 圃 場からの薬剤而性菌分離頻度は, きわめて低く, 薬剤効 力低下の原因にならない程度のものであった．したがっ $\tau$, 当時の耐性菌関係の研究はもっぱら, 人為的に馴致 培養して得た菌株について行なわれてきた。

その後, 1960 年代にはいり, 特定病害を対象に, 選択 毒性の高い殺菌剂が研究され, 抗生物質をはじめ, 多く の優れた特効薬的殺菌郕が開発された. 選択毒性の高い 薬剂ほど耐性菌ができやすい傾向を示すことは, 医薬の 領域では常識であり, とうぜん, 農薬として, 選択毒性 の高い殺菌剂を使えば, 最も先に問題になるのは, 耐性 菌の猖獗であると思われる. 当時の開発研究関係者は, 医薬の䡴を踏えではと，実用に際しては，細心の注意を 払った。たとえば，1960 年ごろ，ブラストサイジン S の実用化に当たっては, 当初, 極力単剂の使用を避け, 有機水銀化合物との混合剤で使用した.

1960 年代の後半ごろから, 農薬の環境污染問題が社会 的に論議され，重金属を含まない有機化合物が選抜の対 象となった。 そのうえ，1969 年に，有機水銀剤が全面使
用禁止になり，薬剤耐性菌の出現がいっそう懸念される ようになったそその翌々年の 1971 年に, 山形県庄内地 方で, カスガマイシンのイネいもち病に対する防除効果 が著しく低下する現象が認められ，農技研および山形農 試で調べた結果, 耐性菌の増加によるものと判明した。 時を同じくして，鳥取県米子地方では，ポリオキシン耐 性のナシ黑斑病菌がかなり高い頻度で検出され，ポリオ キシンの効果が急激に低下することが問題になった。

このときを境に，国内外で，薬戍耐性菌問題がクロー ズアップされた．わが国では，カスガマイシン，ポリオ キシンのほかにベンズイミダゾール系化合物の耐性菌 が，とくに，問題になった。一方，諸外国では，90\% 以 上の報告が，ベンズイミダゾール系化合物の耐性菌に関 するものである．これらの耐性菌に関する現状について は，多くの優れた総説があるので，本誌では，できるだ け重複を避けて，簡単に述べることとし，主として耐性 菌の本質について考えてみたいと思う。

\section{薬剤耐性問題における実例}

日本植物防疫協会の昭和 50 年に集めたアンケート調 查の資料によれば1)，薬剂耐性菌の出現が原因で薬効が 低下したと思われる実例が，いままでに50 件あり，そ のうち，ベンズイミダゾール系およびチオファネート系 化合物が約半数を占めている．その波及する病害は，キ ニウリ・メロンのうどんこ病，灰色かび病，ナスうどん こ病, 温州ミカン青かび病, 緑かび病, リンゴ黑星病な ぞである. 次に多いものに，ポリオキシン郕が 5 分の 1 を占め，その波及する病害は，ナシ黑斑病，リンゴ斑点 落葉病，イチゴ灰色かび病である。 
これら耐性菌出現の実例のほとえどは, 薬剤使用開始 から効力低下が認められるまでの年数は, 平均 $2 \sim 3$ 年 である. 早いものには, 1 年で薬戍が低下している. 使 用回数については, 平均で年 10 回である. 以上の結果 は，各地の試験場および大学からの資料で，現実はもっ と深刻ではないかと思われる。

次に, 植物細菌病害, そ菜病害, 果樹病害, 花き病害 における耐性菌問題について, 述べてみたいと思う.

\section{1. 植物細菌病防除における耐性菌問題}

植物細菌病防除には，古くから，銅刜が用いられ，約 20 年前から, 医薬用として開発された，ストレプトマイ シン, テトラサイクリン系化合物，クロラムフェニコー ル，ノボビオシンなどいくつかの抗生物質が利用されて きた.しかしながら，効果の面では，必ずしも満足でき るものではなかった。 その理由の一つとして，自然界に は, 既存の薬剤に対して非感受性の系統がかなり高い比 率で分布していることによるものと思われる.

これらの薬剤のうち, 圧倒的に, ストレプトマイシン の使用量が多く，稲作・そ菜・果樹など広い範囲の細菌 病防除に使用されてきた。したがって，耐性菌について の報告も多く, 1956 年, 使用開始してから約 2 年で, タバコ野火病に耐性菌が認められた2). わが国では，夕 バコ試験所報告によれば, 本薬剂を連用した地区から, 10 $\mathrm{ppm}$ 以上の耐性菌がかなり高い頻度で分離されるが,使 用して間もない地区からも検出された ${ }^{3)}$. クワ縮葉細菌 病については, 12 都県から採集した菌株から，ストレプ トマイシン耐性菌が, かなり高い頻度で, 検出され，その 検出率に地域差は認められなかっだ). 全国各地のイネ 白葉枯病罹病葉から分離した白葉枯病菌 (Xanthomonas oryzae) のなかには，ストレプトマイシン耐性菌が，か なり高い比率で存在することが報告されている5). しか しながら，近年，作物に対する薬害と医薬に絡んだ耐性 菌問題で，使用量は減少している.

テトラサイクリン系化合物については, 欧米諸国で, ス トレプトマイシン耐性菌出現防止に, 混合剤として使用 している程度である.クロラムフェニコールについては, ここ $2 \sim 3$ 年はほとえど使用されていないようである.

\section{2. そ菜病害における耐性菌問題}

そ菜病害の防除薬剤で, $90 \%$ 以上がベンズイミダゾー ル系化合物の耐性菌である. 国内外を通じて, 多くの作 物のうどんこ病菌, 灰色かび病菌などに発生し，その報 告は枚挙にいとまがない. 外国の発生率については, 上 杉6), Dekker 7) の総説を参照されたい.

わが国では, 前述のとおり, 多くの発生例が報告され ている. チオフォネートミチルおよびベンズイミダゾー
ル系化合物耐性の死色かび病菌については，ハウス栽培

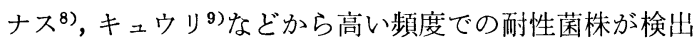
された。それらの耐性菌と感性菌を, 菌系発育, 胞子形 成, 菌核形成, 病原性などで比較した結果, 雨者に著し い差は認められなかっだ0).さらに，八ウス栽培のトマ トに発生するべノミル耐性の灰色かび病菌はポリオキシ ン剂, スルフェン酸系剤で抑制し， 1 年間，上記薬剤の 使用で消滅した。この耐性菌と感性菌とを宿主に混合接 種した結果，チオフォネートミチルの散布で，耐性菌が 増加し, スルフェン酸系剤の散布では, 感性菌が徐々に 増える傾向を示した ${ }^{11)}$. その他の病害については，德島 県下で, 1971 年ごろから, ナス黑枯病の防除に使われた チオフォネートミチルの効力が, 1975 年ごろから著しく 低下した. その原因については, 耐性菌の増加によるも のと考えられた ${ }^{12)}$.

\section{3. 果樹病害における耐性菌問題}

1960 年代に柑橘類の貯蔵病害防除に用いた Diphenyl 剂の耐性菌について，いくつか報告されたほか，固場に おける耐性菌はあまり問題にされなかった. 1968 年ごろ に, ニューヨーク州のリンゴ園で, Dodine 郕の黑星病 に対する効果が著しく低下する現象が認められ，その原 因は，耐性菌の出現によるものと考えられた ${ }^{13)}$ のはじ め, 1971 年ごろに前述の鳥取県において, ナシ黑斑病

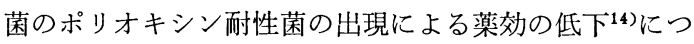
づいて, リンゴ斑点落葉病菌のポリオキシン耐性菌の発 生 ${ }^{15,16)}$ が問題になった。 ポリオキシン耐性のナシ黑斑病 菌は 4 年間同剤の使用を中止しても, 耐性菌は検出され たが，分布比は明らかに漸減する17).

1973 年北海道のリンゴ園で黒星病に対する ベンスイ ミダゾールおよア゙チオフォネートミチル系殺菌剈の効力 低下が認められた. 調べた結果, 耐性菌の出現によるも のと判明した ${ }^{18)}$. さらに, ベンズイミダゾールおよでチ オファネートミチル耐性のナシ黒星病菌は, 感性菌と比 較し, 発芽管の伸長に差は諗められたが, 発芽率に差は なく,ダイホルタン,キャプタン, オキシン銅など数種 の薬剤に対し, 交差耐性が認められなかった ${ }^{19)}$.

\section{4. 稲作病害における耐性菌問題}

わが国の稲作病害防除に用いられている薬刜の大半 は, いもち病防除用であり, 主として, 抗生物質のカス ガマイシン, ブラストサイジン S, 有機リン殺菌剤の IBP など, 有機塩素系殺菌剂のフサライドおよび最近開 発されたプロベナゾール・イソプロチオランである.さ らに, 紋枯病防除には, ポリオキシン, バリダマイシン および有機ヒ素剤がある。現在，紋枯病菌の薬剤耐性に ついては, まだ問題化されていないが，いもち病菌防除 
薬剤については, 今日の耐性菌問題の渦中にある.

前に述べたとおり，1971 年 (使用開始から 5 年目)ご ろに, 山形県庄内地方において, カスガマイシンの使用 に効力の著しい低下が認められ，この現象は，耐性菌の 激発によるものと認められた ${ }^{20)}$. 薬効は急速に低下し, 翌 1972 年には, まったく効果が認められなくなった ${ }^{21)}$. しかしながら，カスガマイシン使用中止 2 年目には薬剤 効果が急速に回復するが，その後の回復率は，かなり緩 慢であり, 薬剤使用当初の薬効に, もどりにくいようで ある22).

次に, 耐性菌の病原性については, 感性菌と比較して, 菌糸の生育, 胞子の形成, イネに打痌斑数, 病斑長 には, 全般的に, かなり変動がみられたが, 同一圃場の感 性菌と耐性菌間では，はっきりした違いはなかった ${ }^{23)}$. さらに，圃場においては，同一罹病部または一病斑から， 耐性菌と感性菌の雨者がともに分離されることはなかっ た ${ }^{23)}$. また, カスガマイシンを散布したイネ葉での病斑 はいずれも耐性菌由来のものだが，カスガマイシン無散 布イネに両菌株を接種した結果, 山形県産の菌株につい て，例外は認められたが,形成された病斑のほとんどは， 感性菌由来のものであった ${ }^{11)}$.

上述の耐性菌は, 他のいもち病防除薬剤に対して，ほと んど,交差耐性を示さず24), とくにフサライドでは, $100 \%$ に近い防除効果を示した ${ }^{24 ~ 26)}$. しかしながら，培地上で の菌糸生育, 胞子発芽扎よびポット試験では, ブラスト サイジン Sに対して, 交差耐性を示し, 新潟県下では, カスガマイシン耐性菌分布に地域差が認められ，フサラ イドに比して，ブラストサイジン S, キタジンの防除効 果が劣るなどの報告もあった ${ }^{27,28)}$.

有機リン剂に対する耐性菌に関しては, 固場で, 著し い効力の低下現象は，まだみられないが，1976 年，富山 県下の戋場で分離した 173 株のいもち病菌について, 調 ベた結果, 8 菌株が薬剤耐性菌であることが認められた。 これらの菌株は，いずれも EDDP およびィソプロチオ ランに対して交差耐性を示した ${ }^{29)}$. さらに, 新潟県内の 103 地点から分離したイネいもち病菌 868 菌株につい て, IBP 感受性をイネ生葉寒天培地で, その最大生育濃 度 (MAC) を調べた結果, $10 \sim 50 \mu \mathrm{g} / \mathrm{ml}$ の範囲内で 2 峰 性分布を示し, 耐性菌存在を示唆するものである ${ }^{30)}$.

\section{5. 花き病害における薬威耐性菌問題}

1970 年ごろから，国内外で，花き病害防除に使用して いる薬剤に対して, 耐性菌の出現が, 問題になった。才 ランダでは, シクラメンの灰色かび病 ${ }^{31)}$, ユリの dry rot 病 $^{32)}$, アメリカ・カリフォルニア州のキク灰色かび病 ${ }^{33)}$, グラジオラスの病害 ${ }^{34}$ などの防除に, ベノミル耐性菌の
発生例が報告されている.

わが国では，キク白さび病防除におけるオキシカルボ キシン耐性菌が問題になっている. 従来, 本病害に対し ては, 水和硫黄, マンネブ剤, アンバム用, キャプタン 剤などが用いられたが，これらの薬剤は効果の面で不十 分な点があるうえに, 植物体上で, 污点を生ずる欠点が ある.この理由で, 1971 年から, 本病の防除には, もっ ぱら, 効果の優れたオキシカルボキシン（プラントバッ クス）を用いてきた. しかるに, 1973 年, 奈良県, 三重 県下において, ポットマム栽培の一部の温室で, 常用濃 度以上のオキシカルボキシンを散布しても, 本来の防除 効果を示さず, キクの白さび病の激発で問題になった。 現在, 対策として, 他の薬剤と交互使用, 混用など, 試 みられている35).

以上, 固場における薬剤耐性菌の発生例を報告に基づ いて，簡単に紹介させていただいたが，ほかに，多くの 未発表例があると思う。

\section{植物病害防除における薬剤耐性菌の本質}

戋場における薬斉耐性菌が問題になってから 7〜8 年 経過したが, 基礎的な研究は, 緒についたばかりで, 不 明な点が多い。たとえば，耐性菌出現の原因，耐性菌の 耐性機構，耐性菌の全国的分布状況，さらに，耐性菌の 増加や出現を防止するに必要な基礎的知見などがある. そこで, 本章では, 推定の域を脱しえないことがあろう と思うが，ここで，若干の検討を行ない，今後の研究に， わずかでも参考になれば，幸いと思う。

\section{1. 薬剤耐性菌出現の原因}

一般に, 同一薬剤を単剂で連用，とくに，特異性の高 い薬剤の使用は, 耐性菌の出現を誘致しやすいことは, 衆知のとおりである。しかしながら，出現した耐性菌が 感性菌株から，薬剤の作用によって，徐々に馴致され， 耐性度が増加する，いわゆる，獲得酎性菌か，あるいは， 自然界に棲息する自然抵抗性菌が薬剤の淘汰によって, 增加した自然抵抗性菌かは, 不明であり, 現在, それを 証明する決定的な手段はない.

室内における耐性菌の研究には, 古く 1962 年の馴致 培養によって得られたブラストサイジン S 耐性菌株 ${ }^{36)}$ と実用濃度以上の薬剤を含えだ培地上に植菌して，分離 したカスガマイシン耐性菌株 ${ }^{37)}$ の報告例がある．前者 は, 獲得耐性菌で, 後者は自然淘汰耐性菌である。

そのほかに, 薬剤と接触した時点で変異あるいは薬剤 を不活化する能力の誘発で耐性菌株が生ずる場合もあり うる。筆者も，1968 年ごろに，培地上で保存菌株からポ リオキシンの $2,000 \mathrm{ppm}$ 自然淘汰耐性，および 10,000 
ppm 獲得耐性のナシ黑斑病菌を分離した経験がある.

これらのことから，分布比率は明らかではないが，自 然において, 少なくとも, この 2 種類の耐性菌の存在が 可能と思われる.

しかしながら，前述の耐性菌発生例およびその後の生 物学的所見，たとえば，感性菌と耐性菌を混合接種した 場合, 薬剤の存在下では, 形成された病斑のほとんどは, 耐性菌由来のものであるが，薬剤の存在しない場合に形 成された病斑は感性菌由来のものであること ${ }^{19)}$, 薬用無 散布地区から, 頻度は高くないが, 常時, 耐性菌が検出 されること，使用開始から耐性菌出現の期間が短いこと などから 1 ，自然界に存在する耐性菌は，薬剤によって 圃場で馴致されて出現した可能性が低く，むしろ，薬剤 の淘汰压によって, 感性菌・耐性菌の比率均衡が崩れ, 自然界に存在する非感受性菌（あるいは抵抗性菌）が増 加したと考えたほうが妥当である.

さらに, 自然界に打いて, もし, 獲得耐性菌が出現す るとすれば, 土壌中に棲息する病原菌が, 常時, 残留し た薬剤の有効成分と接触する機会があるうえに, 濃度の 定時的増加が必要条件になるものと思う. このことから 考元, 自然界において獲得耐性菌の出現する可能性は少 ないと思う。しかしながら, 突然変異を誘発する可能性 の高い化合物の施用によって耐性菌が誘発される可能性 は，否定できない。

次に考えるべき問題として，自然界においてきわめて 低い割合で分布している耐性菌が, 薬剤の散布によって, 急速に増加する原因である. 一般に，自然界において異 種間の生物が互いに拮抗する現象は, 広く知られている ものであるが, 同種内の菌同士については, 1923 年才ラ ンダの D. M. Cayley が, 単胞子で分離した菌株を対峙培 養すると, 生育境界面に互いに生育し合わない阻害領域 が形成される現象を見つけ，これを aversion と名づけた。

この現象は, 同種菌の異系統間の拮抗現象で, その後, 数多くの実験例が報告されている. 植物病原菌について も, 最近, Cochliobolus lunata についての報告がある ${ }^{38)}$. この現象は自然界において, 大部分の感性菌と小部分の 耐性菌の分布比率は, 病原菌特有の aversionによって支 配されていて, 感性菌の薬剤による除去が耐性菌の増加 の原因の一つと考えられ，このことは，前述の耐性菌， 感性菌の混合接種で, 薬剤のない条件下では形成された 病斑のほとんどが, 感性菌由来のものであることから裏 づけられるものであるが, 今後, さらに, 直接的な証明 を期待したい。

\section{2. 耐性機構および交差耐性}

酎性菌の薬剤に対する 耐性機構については, 1952 年
Danis ${ }^{39)}$ らが七つの仮説を立てた。すなわち (1) 薬剤の 菌体への透過の低下, (2) 薬郕の分解の促進（あるい は，活性のない化合物から活性のある化合物の変換の低 下), (3) 拮抗物質の増加, (4) 作用点とする酵素の増加, (5) 作用点での代謝産物が，生体にとって 量的に必要性 が減少した，(6) 作用とする代謝経路に by-pass が生じ た，(7) 作用点とする酵素の薬剤に対する親和性の低下. それから 20 数年経過したが, 医療用薬剤の耐性菌の研 究報告から，(1) (2) (7) が多く, (3) (4) (6) はほとんどその 例を見ない。

(1) の例では, 室内で馴致して得たブラストサイジン S 2,000 ppm 耐性菌株の生菌体系と無細胞系の蛋白合成 に対する作用の違いから, その耐性機構は, 薬剤の耐性 菌体への透過性の低下によるものと推定した ${ }^{40)}$. 最近, 鳥取県米子地方から分離したナシ黒斑病菌のポリオキシ ン耐性菌株（Yr-107）と感性菌株（Es-1）の菌体を用い, ${ }^{14} \mathrm{C}$-ポリオキシンの透過性を調べた結果, 耐性菌株の ${ }^{14} \mathrm{C}$-ポリオキシンに対する透過性が著しく低下し, この

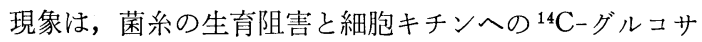
ミンの取込阻害とは明らかに関連があることが報告され た ${ }^{41)}$.

(2)の例としては，現存の農薬ではまだ知られていな いが，医療用殺菌剤ではかなり多くの例が報告されてい る. 最も有名なものとして, ペニシリン感性のブドウ球 菌がペニシリン処理を受けると, 適応酵素としてペニシ リナーゼが生産され, その菌体がペニシリン耐性菌にな る報告である ${ }^{42)}$.

最後に，(7)の例については，医薬においてかなり報 告例が多い. ストレプトマイシンでは, 耐性菌リボゾー ムの $30 \mathrm{~S}$ 粒子を含を蛋白合成反応系だけが，ストレプ トマイシンに耐性を示し ${ }^{43)}$, とくに, $30 \mathrm{~S}$ リボゾームに 含まれる Core Protein に依存することが報告された ${ }^{44)}$. カスガマイシン耐性菌の耐性機構についても, 室内で分 離した $100 \mathrm{ppm}$ カスガマイシン耐性菌の耐性機構は, リボゾームの薬剤に対する親和性の違いによることが明 らかになった

一般に，耐性機構および交差耐性については，薬剤の もつ作用性やその機構に依存することが多いといわれて いる.たとえば， ベノミルとトップジン $\mathrm{M}$ では，一 見，異なった化学構造をむっているが，それらの代謝 中間体で, 活性のある代謝物と考えられている BCM (Benzimidazole carbamic acid, methyl ester) は共通のも のであり ${ }^{46)}$ ，その作用機構は，まったく類似するもので ある、したがって，この系統の化合物は，ほとんどの場 合，互いに交差耐性を示すことが知られている。 
しかしながら，現存の薬荗で論じた場合，どの程度に 作用機構の類似性があれば, 交差耐性を示すかは不明で ある．たとえば，同じ蛋白合成を阻害するカスガマイシ ンとブラストサイジン Sでは，容易に交差耐性を示すと は考えられない，同じアミノ配糖体抗生物質であるスト レプトマイシンとカスガマイシンでは, 同じく蛋白合成 系に作用するが，抗菌性がかなり異なり，交差耐性を示 す可能性む低い。さらに, 現在使用されている薬郕中, 前述のべノミルとトップジン $\mathrm{M}$ の作用機構のように類 似性をもった化合物はない。

したがって，作用機構や耐性機構から，交差耐性出現 の可能性を類推することは，はなはだむずかしく，資料 不足の感がする，そのう元，耐性菌の出現が薬浏の作用 機構や耐性機構の完全なる支配を受けずに，前述のとお り，単純に，自然界において，抵抗性菌に対する薬剤の 選別によるものであれば，たとえ 2 㘊あるいは 3 剂の混 合剤を使用しても，出現頻度はやや低くなるが，2 郕以 上の交差耐性をもった耐性菌株の出現する可能は高いも のと思われる。

前述のと打り，ベンズイミダゾールおよびチオファネ 一ト系化合物の耐性菌出現はきわめて早く，場合によっ ては, 使用して数回で, 耐性菌の出現で薬剤が低下する 現象がみられた。しかしながら，これらの薬剤の生物活 性, 抗菌スペクトル, 適応範囲から考えた場合, 他の薬 剂にくらべると特異性がなく, 耐性菌を誘発する可能性 は低いと考えられがちで，事実とは著しく相違するもの である。したがって，現在使用されている薬郕のなかで， DNA の合成に作用する薬剤 ${ }^{47 \sim 49}$ は, この系統のもので， 薬剂の作用機構が, 耐性菌の誘発に関与するものと推察 する。

\section{おわりに}

植物病害防除に抢ける耐性菌の研究はやっと軌道に乗 ったばかりで，多くの研究課題が残されている。

たとえば, 耐性菌の疫学的問題 ${ }^{50)}$, 出現の機構および 耐性の伝達などがある. 最近の興味ある研究としては, 20 年前から, 細菌の薬刘耐性, とくに多剂耐性の伝達 機構で, 深く研究されてきた $\mathrm{R}$ 因子 ( $\mathrm{R}$ plasmid) が植 物病原細菌, Xanthomonas vesicatoria のプラミッド由 来 carbenicillin 耐性菌でも見つかった報告 ${ }^{11}$ がある。乙 かしながら，植物病原系状菌については，まったくこの 方面の研究は行なわれていない.

このような，基礎研究を進めるに当たって，当面行な わなければならないのは, 自然界における耐性菌の分布 状況であり, 今後の研究の基本的資料として欠くべから
ざるものである. 最近, この方面の報告 ${ }^{52)}$ 出はじめて いるようで，ある程度の体系化が望まれる。将来，これ らの疫学的調查から, 菌学的に整理し, 病理学的研究に おけるレースや系統分類のように，耐性菌に打いても， 各薬剂に対する感受性の異なった菌株の drug-strain や drug-clone を保存する機関を設け，新薬剤の開発のさい に，交差耐性あるいは耐性打破などの性質をチェックで きれば，耐性菌防止対策には大いに役立つもの之思う。 その理由で, 筆者は, 数年前から, 絶対寄生菌であって 薬戍而性菌の出現しやすいキュウリうどんこ病菌を用い て, 数種薬剤の耐性菌出現率, 出現速度打よび交差耐性 を調べた。この種の報告も，他の絶対寄生菌について， その資料を期待したい.

最後に, 薬郕耐性菌の防止対策として，よく同一薬剤 の連用を避け，作用機構の異なる薬剂を混用，あるいは 交互使用をされることが望ましいといわれているが，前 述の理由，すなわち，多剤耐性を誘発する結果になる危 険性があり，現時点では決して良策ではない。むしろ， 特異性の低い薬剂を多く開発し，1 薬郕について，1 年 の間散布回数を 1 回に限定し, 多くの薬拜を用い, 薬郕 の特性に従って対象病害あるいは作物の生育に合う薬郕 を使用し，年単位で防除計画を作るべきである。

\section{引用 文 献}

1）飯田 格：植物防疫 29, 163 (1975)

2) L. Shaw \& G. W. Thorne: Plant Dis. Rep. 40, 325 (1956)

3）前田 進・山口洋一：秦野たばこ試報 70, 91, (1971)

4） 高橋幸吉： 植物防疫 29, 199 (1975)

5）脇本 哲・向 秀夫：日植病報 28, 153 (1963)

6）上杉康彦：植物防疫 29,167 (1975)

7) J. Dekker: Ann. Rev. Phytopathol. 14, 405 (1976)

8）手塚信夫・木曽 皓：日植病報 41，303 (1975)

9）山本 磐： 植物防疫 29, 194 (1975)

10）手塚信夫・木曾 皓：日植病学会 53 年度大会講 演要旨集 No. 249, (1978)

11）竹内妙子・長井雄治：日植病学会 53 年度大会講 演要旨集 No. 247, (1978)

12）福西 務：日植病学会 53 年度大会講演要旨集 No. 246, (1974)

13) J. D. Gilpatrich \& D. R. Blowers: Phytopathology 64, 649 (1974)

14）西村正暢 - 甲元啓介 - 宇田川英夫：植物防疫 26, 157 (1972)

15） 江口 潤-最上 信 - 奥田四郎：日植病報 $\mathbf{4 0 , 2 2 0}$ (1974)

16）藤田肖子・桜井 寿：日植病報 $\mathbf{4 3}, 360$ (1977)

17）三宅英夫・高垣寛男・甲元啓介・西村正暢：日植 
病報 41，100(1975)

18）沢村健三：植物防疫 29, 187 (1975)

19）石井英夫 -山口 昭：日植病報 43，557 (1977)

20）三浦春夫 - 伊藤 弘 -木村和夫 - 高橋昭二：日植 病報 39, 239 (1973)

21）伊藤 弘・三浦春夫・高橋昭二：日植病報 $\mathbf{4 0}, 220$ (1974)

22) 三浦春夫： 植物防疫 29, 183 (1975)

23）三浦春夫 · 片桐政子 - 山口富夫 · 上杉康彦 - 伊藤 弘：日植病報 40,220 (1974)

24）三浦春夫 - ・片桐政子・高橋昭二：日植病報 41, 302 (1975)

25）片桐政子・上杉康彦：日植病報 39，239 (1973)

26）三浦春夫 - 高橋昭二：日植病報 43，357 (1977)

27）桜井 寿 -内藤 久・吉田孝二：日植病報 $\mathbf{4 1}$, 303 (1975)

28）矢尾板恒雄 - 郷 直俊 - 青柳和雄 - 桜井 寿：日 植病報 43，357 (1977)

29）片桐政子・上杉康彦・梅原吉広：日植病協会 53 年度大会講演要旨集 No. 236, (1978)

30）矢尾板恒雄 - 鄉 直俊 - 青柳和雄 - 桜井 寿: 日 植病協会 53 年度大会講演要旨集 No. 237, (1978)

31) G. J. Bollen: Neth. J. Plant Pathol. 77, 83 (1971)

32) G. J. Bollen: ibid. 77, 187 (1971)

33) A. G. Watson \& C. E. Koons: Phytopathology 63, 1218 (1973)

34) R. O. Magie \& G. J. Wilfret: Plant Dis. Rep. 58, 256 (1974)

35）我孫子和雄：植物防疫 29,35 (1975)
36) 中村廣明 - 桜井 寿：植物防疫 27, 84 (1962)

37) K. Ohmori: Nogyo Gijitsu 21, 479 (1966)

38）貫名 学・ 丸茂晋吾：日植病学会大会講演要旨集 No. 68, (1978)

39) B. D. Davis \& W. K. Mass: Proc. Natl. Acad. Sci. 38, 775 (1952)

40) K. T. Huang, T. Misato \& H. Asuyama: J. Antibiot. 17, 71 (1964)

41) M. Hori, K. Kakiki \& T. Misato: J. Pesticide Sci. 1, 31 (1976)

42) W. M. M. Kirby: Science 99, 452 (1944)

43) E. C. Cox, J. R. White \& J. G. Flaks: Proc. Natl. Acad. Sci. U.S. 51, 703 (1964)

44) P. Traub \& M. Nomura: Science 160, 198 (1968)

45）黄 耿堂・星野ゆり・見里朝正：日植物病報 35 , 134 (1969)

46) G. P. Clermons \& H. D. Sisler: Phytopathology 59, 705 (1971)

47) G. P. Clemons \& H. D. Sisler: Pestic. Biochem. Physiol. 1, 32 (1970)

48) Hammerschlag, K. S. \& H. D. Sisler: Pestic. Biochem. Physiol. 3, 42 (1972)

49) Davidoe, L. C.: ibid. 3, 317 (1973)

50) 桜井 寿：日本農薬学会誌 2, 177 (1977)

51) M. Lai, S. Shaffer \& N. J. Panopoulos: Phytopathology 67, 1527 (1977)

52) 桜井 寿 - 藤田肖子 - 内藤 久：日本農薬学会誌 2, 249 (1977) 